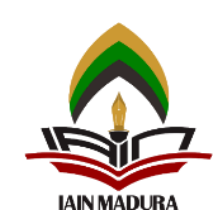

\title{
Konstruksi Dakwah Multikultural Kiai Lokal Era Modern
} (Studi Kasus Kiai Di Tuban)

\author{
Shima Nahara \\ Manajemen Dakwah Universitas Islam Negeri Sayyid Ali Rahmatullah Tulungagung \\ Shimanahara9@gmail.com \\ Ahmad Nurcholis \\ Manajemen Dakwah Universitas Islam Negeri Sayyid Ali Rahmatullah Tulungagung \\ cholisahmad87@gmail.com
}

\begin{abstract}
Abstrak
Penelitian ini berfokus pada pembahasan mengenai: bagaimana implementasi dakwah multikultural era modern kiai-kiai lokal di Tuban, apa peran dakwah multikultural era modern kiai-kiai lokal terhadap masyarakat Tuban. Tujuan penelitian ini adalah: mengetahui implementasi dakwah multikultural era modern kiai-kiai lokal di Tuban, mengetahui peran dakwah multikultural era modern kiai-kiai lokal terhadap masyarakat Tuban. Melalui pendekatan kepustakaan dan pendekatan lapangan yang sebagaimana penelitian kualitatif lainnya, kemudian dengan metode deskriptif penelitian ini akan dijabarkan secara lengkap. Hasil dari analisis ini memperlihatkan bahwa Indonesia merupakan negara multikultural, multikultural itu sendiri ialah keberagaman budaya, bahasa, suku, warna kulit, agama. Untuk dakwah multikultural itu merupakan upaya seorang da'I untuk menyampaikan pesan dakwah dalam masyarakat yang multikultural tanpa adanya perselisihan, agar terciptanya suatu kedamaian dan keharmonisan. Diantara beberapa kota yang ada di Indonesia yang telah menerapkan dakwah multikultural ialah kota Tuban. Kiai-kiai lokal yang ada di Tuban sangatlah berperan dalam berjalannya dakwah multikultural, apalagi di era modern ini. Banyak problem-problem yang muncul pada era ini. Oleh sebab itu kiai-kiai lokal di Tuban berdakwahnya harus mengikuti zaman yang telah maju untuk berhadapan dengan masyarakat multikultural era modern agar terciptanya dakwah yang efektif dan efisien.
\end{abstract}

Kata Kunci: Dakwah Multikultural, Kiai Lokal, Masyarakat Modern.

\section{Abstract}

This research is entitled "Construction of Multicultural Da'wah of Modern Local Kiai (Case Study of Kiai In Tuban)". This research focuses on the discussion of: how to implement the modern era multicultural da'wah of local kiai in Tuban, what is the role of modern era multicultural da'wah of local kiai to the people of Tuban. The objectives of this study were: to determine the implementation of the modern era multicultural da'wah of local kiai in Tuban, to find out the role of modern era multicultural da'wah of local kiai to the Tuban community. Through a library approach and a field approach, as with other qualitative research, then with a descriptive method this research will be described in full. The results of this analysis show that Indonesia is a multicultural country, multicultural itself is the diversity of culture, language, ethnicity, skin color, religion. For multicultural da'wah, it is an attempt by a da'I to convey the message of da'wah in a multicultural society without any disputes, in order to 


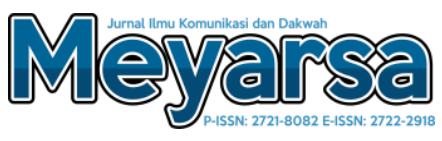

create peace and harmony. Among several cities in Indonesia that have implemented multicultural da'wah is the city of Tuban. The local kiai in Tuban are very instrumental in the passage of multicultural da'wah, especially in this modern era. Many problems arise in this era. Therefore, local kiai in Tuban preaching must follow the times that have advanced to deal with multicultural society in the modern era in order to create effective and efficient da'wah.

Keywords: Multicultural Da'wah, Local Kiai, Modern Society

\section{Pendahuluan}

Secara horizontal, Indonesia adalah negara yang memiliki berbagai ras, budaya, bahasa, adat istiadat dan kepercayaan yang berbeda. sedangkan secara vertikal, Indonesia sangat beragam ditingkat pekerjaan, tingkat ekonomi, pendidikan dan sosial budaya masyarakat. Keberagaman di Indonesia merupakan sosialisasi ajaran agama turun-temurun dari nenek moyang yang diakulturasi dengan kebudayaan masyarakat sehingga muncul beberapa agama di Indonesia dengan ritual keagamaan yang beraneka ragam. ${ }^{1}$

Sebagai agama dengan penganut tertinggi di Indonesia, Islam memiliki sejarah penyebarannya di Indonesia dalam 3 teori yaitu: teori Gujarat, Mekah dan Persia. Strategi Islam masuk ke Indonesia melalui jalur damai, dan menggunakan saluran perdagangan dan perkawinan. Dengan jalur kedua tersebut Islam menyebar dengan cepat di Indonesia. Kemajuanan Islam yang cepat mengakibatkan munculnya dai yang membabarkan Islam memakai jalur pendidikan dengan

${ }^{1}$ Indonesia telah mengakui secara sah ada 5 agama yang yaitu: Islam, Kristen Protestan, Katolik, Hindu, Buddha, dan Kong $\mathrm{Hu} \mathrm{Cu}$. Dengan komposisi Islam jumlah penganutnya 207.177 Jiwa (87.19\%), kristen prostestan jumlah penganutnya 16.528.514 Jiwa (6,97\%), Katolik jumlah penganutnya 6.907.874 Jiwa (2.92\%), Hindu jumlah penganutnya 4.012.117 Jiwa (1.6,97\%), buddha jumlah penganutnya 1.703.255 Jiwa (0,73\%), Kong $\mathrm{Hu} \mathrm{Cu}$ jumlah penganutnya 117.092 Jiwa (0,06\%). mendirikan pesantren, pesantren sendiri merupakan kawasan anak muda dari beberapa wilayah dan kalangan masyarakat untuk menuntut ilmu agama Islam, setelah lulus dari pesantren anak muda membabarkan islam diwilayahnya sendirisendiri. Selain dengan jalur perdagangan, pendidikan, penyebaran Islam juga melalui jalur kebudaya dan kesenian, seperti contoh pertunjukan wayang.

Strategi pembabaran Islam di nusantara tidak terputus dari para Wali Songo. Wali Songo dikenal sebagai pembabar ajaran Islam di wilayah jawa pada tahun ke 1400 hingga 1800. Wilayah penyebaran di pesisir utara yaitu: Surabaya, Gresik, Lamongan, Tuban, Demak, Muria, Kudus, Cirebon. Wali Songo tersebut ialah: Sunan Gresik, Sunan Ampel, Sunan Bonang, Sunan Drajat, Sunan Giri, Sunan Kudus, Sunan Kalijaga, Sunan Muria, Sunan Gunung Jati. Penyampaian dakwah Islam yang dilakukan oleh Wali Songo dengan mengakulturasi budaya masyarakat Jawa yang kental akan ritual keagamaan.

Tuban merupakan salah satu pusat dari dakwahnya para wali. Wali yang berada di tuban ialah Sunan Bonang (Raden Makdum Ibrahim).Sunan Bonang pada saat itu berdakwah dengan menggunakan kebudayaan dan kesenian seperti suluksuluk yang sudah diciptakannya. Dengan kesenian dan kebudayaan tersebut, masyarakat Tuban menerimanya dengan baik, sehingga bisa dikatakan dakwahnya Sunan Bonang berhasil pada saat itu. 


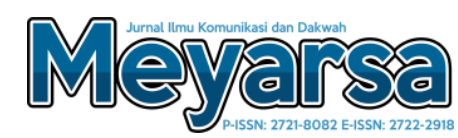

Era sekarang berbeda dengan era pada masa wali songo. Era modern ini, pendidikan Islam merupakan aspek penting yang menjadi landasan, agar umat manusia tidak kalah dengan moralitas yang semakin tergerus dan mengkhawatirkan. Pembelajaran Islam berkedudukan aktif dalam mewujudkan paradigma yang semestinya. Indonesia adalah wilayah multikultural dengan keragaman budaya, ras, suku, dan agama yang niscaya menggugah perhatian dan menjadi titik saling mempengaruhi. Ketika tidak bisa saling menghormati, tentu akan terjadi berbagai perselisihan yang akan menimbulkan banyak masalah dan pertikaian.

Di masa modern ini, masyarakat perlu meningkatkan rasa saling menyegani dan mengapresiasi keanekaragaman perbedaan, agar tidak terjadi konflik. Maka dari itu, pembelajaran Islam yang multikultural bisa memerkuat segala ketidaksamaan yang berada dikalangan umum. Masyarakat masa kini mempunyai nilai-nilai kultur yang mengarah pada aktivitas yang sistematis saat ini. Kebiasaan masyarakat masa kini adalah menyelusuri hal-hal yang ringan guna menyatukan nilai-nilai lama dengan budaya otoritas modern untuk kesenangan individu. Akibatnya, praktik-praktik kotor seperti nepotisme dan korupsi bermunculan yang berakibat pada kualitas yang sangat rendah. Oleh karena itu, inilah pekerjaan rumah pendakwah era modern saat ini.

Mengedepankan multikulturalisme berarti menciptakan keharmonisan dalam masyarakat yang berbeda-beda dan masih mumpuni dalam meneguhkan diri serta mentolerir semua wujud variasi yang tidak setara. Inilah dasar dari strategi multikulturalisme. Pendakwah pada era modern ini pastinya berbeda dengan pendakwah pada era sebelum modern, karena pendakwah itu harus menyesuaikan masyarakat (mad'u)nya. Di sinilah penulis terdorong untuk melakukan penelitian yang berjudul "Konstruksi Dakwah Multikultural Kiai Lokal Era Modern (Studi Kasus Kiai Di Tuban).

\section{Metode Penelitian}

Dalam penelitian ini metode yang dipakai adalah metode penelitian deskriptif kualitatif. Metode tersebut adalah metode yang mendeskripsikan, berupa penjelasan, dan gambaran-gambaran tentang fenomena yang telah terjadi dikehidupan sehari-hari. Sumber data primer yang didapatkan melawati interviu bersama kiai dan masyarakat. Sedangkan sumber data skunder didapatkan melalui interview bersama warga sekeliling Tuban dan dokumen-dokumen atau laporan yang telah tersedia, terutama yang berhubungan dengan kontruksi dakwah multikultural kiai lokal era modern di Tuban. Penelitian yang dilaksanakan secara urut dengan mengupgrade data yang terdapat di lapangan. Teknik pengumpulan data yang digunakan peneliti yaitu wawancara (dengan masyarakat Tuban), observasi dan dokumentasi.Teknik pengolahan data dalam penelitian ini yaitu data akan dikumpulkan, dan data yang ada dapat diproses dan dianalisis pada saat yang bersamaan. Pada tahap ini, pembaca dapat mengembalikan analisis data ke bidang ini untuk menemukan data lain yang dianggap perlu, lalu memproses lagi. 


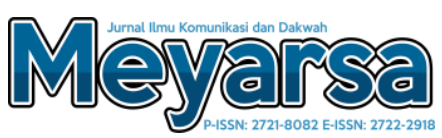

\section{Hasil dan Pembahasan}

\section{Peta Da'i di Tuban}

Tuban merupakan Kabupaten, yang berada di Provinsi Jawa Timur dan berada di perbatasan Provinsi Jawa Tengah. Kabupaten ini memiliki luas kurang lebih 1.907,70 kilometer persegi. Kabupaten Tuban juga dijuluki sebagai kota Wali, namun disisi lain Tuban juga memiliki julukan sebagai kota Tuak. Sebelumnya, tuak adalah minuman beralkohol yang didapat dari ekstrak fermentasi getah pohon siwalan. Selain itu, Tuban memiliki derajat multikulturalisme yang tinggi dan pluralitas yang tinggi. Tuban juga terkenal dengan perlindungan bumi yang bernuansa Islami, meskipun disisi lain disebut Kota Tuak.

Sejarah mengatakan bahwa Tuban memiliki budaya yang bermacam-macam Hal ini dibuktikan pada saat zaman Majapahit, Kabupaten Tuban dijadikan salah satu pelabuhan terbesar yang mana latar belakang mereka menganut agama Hindu-Budha. Menurut fakta sejarah pula, Tuban sudah ada ratusan tahun, sebagai daerah di pesisir pantai Jawa yang masyarakatnya adalah nelayan. Sejak abad ke-11 Tuban dikenal sebagai pelabuhan internasional jauh sebelum Surabaya. Bahkan Ujung Galuh belum dipilih oleh $\mathrm{Mpu}$ Sendok sebagai sebagai basis dan benteng Jawa Timur.

Awal masuknya agama Islam ke pantai utara Jawa Timur diyakini yaitu pada abad ke-11. Terbukti karena ditemukannya sebuah batu nisan di daerah Leran Provinsi Jawa Timur, yang mana bertuliskan nama seorang perempuan yaitu Fatimah Binti Maimun Bin Hibatullah disertai tanggal 495 Hijriyah (1082 Masehi). Pada abad ke12 Masehi ajaran agama Islam pun tersebar ke seluruh pelosok Indonesia, dan pada abad ke-14 dan ke-15 inilah Islam mulai tersebar di pesisir Tuban. ${ }^{2}$

Tak lama setelah itu, datanglah salah satu Wali, yaitu Sunan Bonang yang mana beliau menyebarluaskan agama. Kabupaten ini juga telah lama menghargai perbedaan antara sesamanya dan mampu membangun sifat toleransi atau saling menghargai adanya perbedaan. Hal ini dibuktikan Tuban merupakan pintu gerbang masuknya orang Tionghoa ke Indonesia, dan tercatat sejarah bahwa Panglima Besar Cheng Ho pertama kali berlabuh di pesisir Tuban pada masa Kerajaan Majapahit.

Adapun tahapan islamisasi di pantai utara Jawa Timur diidentifikasikan dengan kehancuran Majapahit dan munculnya kekukuhan baru para saudagar muslim yang telah bermukim di pantai sejak abad ke-11 dan semakin berpengaruh. Keyakinan penduduk yang dibagi ke dalam tingkatan yang bertentangan dengan skema Islam yang setara membuat pesona bagi tahapan Islamisasi tentram.

Menurut data yang ada, umat Islam memiliki jumlah pengikut terbesar, keadaan saat ini tidak terlerai dari strategi dakwah yang diusung oleh Wali Songo yang ternyata memiliki keuntungan nyata bagi kemajuan peta dakwah Islam untuk meningkatan keunggulan ummat dalam berperilaku islami yang masih terdapat

\footnotetext{
2 Teori Gujarati mengutarakan bahwasannya agama Islam masuk ke nusantara pada abad ke-13 melewati kedudukan pedagang India. Teori Mekkah mengutarakan bahwasannya Islam masuk ke nusantara langsung dari Timur Tengah melewati jasa pedagang Muslim Arab sekitar abad ke-7. Teori Persia menunjukkan bahwasannya Islam masuk ke nusantara melewati kedudukan pedagang Persia sekitar abad 13. Setiap teori mempunyai pendapat dan fakta ilmiah, termasuk warisan budaya berwujud batu nisan yang tercantum tuliskan Hufi Arab dan makam penyebar agama Islam.
} 
IAIN MADURA

kesalahpahaman dalam pengamalan prilaku islami.

Proses Islamisasi di pantai utara Jawa Timur tidak lepas dari pengabdian para Wali Songo, khususnya Sunan Ampel, Sunan Giri dan Sunan Bonan. Di sepanjang pantai Jawa Timur banyak terdapat pedagang, kini banyak pula yang beragama Islam. Mereka merupakan pelopor Islam (Muballigh), dan mereka secara tulus dan ikhlas menuntun menggunakan media Islami dengan membangun pesantren dan kesenian. Mereka juga membangun masjid / Langgar.

Tahapan masuknya Islam di daerah pantai Tuban tidak terlepas dari karya dakwah Sunan Bonang, yang mana beliau menggunakan alat seni dan budaya untuk menarik lebih banyak simpati dari warga. Bahkan Sunan Bonang juga dikenal sebagai Wali yang menciptakan dan merancang alat-alat gamelan Jawa yang dinamakan alat musik Bonang, alat musik ini terbuat dari logam dan berupa seperti gong, namun lebih kecil dalam ukuran dan bentuknya. Konon, sebutan alat musik gamelan Bonang ini dikutip dari nama tempat tinggal Sunan Bonang yaitu desa Bonang di kawasan Lasem.

Raden Makdum Ibrhahim atau biasa dikenal sebagai Sunan Bonang beliau merupakan anak ke 4 dari Sunan Ampel. Sunan Bonang beserta Sunan Giri berguru pada Syekh Awwalul Islam dan ulama besar yang tinggal di Pasai. Usai menuntut ilmu di Pasai, mereka berdua kembali ke Pulau Jawa. Sunan Bonang pun diperintah oleh Sunan Ampel untuk menyiarkan Islam di kawasan Lasem, Rembang, Tuban.

Selain alat musik gamelan, ia juga membuat tulisan sastra yang dinamakan Suluk. Tulisan sastra Sunan Bonang ini dipandang sebagai tulisan sastra yang benar-benar agung, banyak keagungan dan makna dalam kegiatan beragama. Suluk Sunan Bonang saat ini masih terabadikan rapi disalah satu ruang yang berada di Universitas Leiden di Belanda. Ada banyak puisi dan karya prosa lainnya yag cukup banyak. Yang termasuk Suluk Wujil, Suluk Khalifah, Suluk Regok, Suluk Bentur, Suluk Wasiyat, Suluk Ing Aewuh, Suluk Pipiringan, Suluk Jebeng, dll. ${ }^{3}$

Pada bagian sebelumnya, situasi geopolitik dan perekonomian sedang menurun. pedagang muslim mulai berdagang. Asal mula mereka adalah pendakwah. Menurut tuntunan Islam, tiada perbedaan antara aktivitas berdagang dan keharusan menyalurkan ajaran Islam untuk pihak lain. Separuh dari mereka berdiam, terima dan gunakan adab dan adat istiadat setempat, dan melakukan pernikahan Islami dengan wanita setempat yang diislamkan.

Sunan Bonang mengubah tradisi kecapi khas Jawa menjadi "slendro pelok" dan memperkenalkan ajaran Islam seperti lagu "Lir Ilir" yang berisi arti dan lambang sembahyang 5 kali sehari. Menggunakan kesenian yang telah mengakar di warga

${ }^{3}$ Sunan Bonang menggunakan wayang Golek dan karya sastra berupa suluk atau tembang Tamsil dalam menyebarkan agama Islam. Ia membuat sendiri beberapa wayang, atau membentuk wayang dengan Sunan Kalijaga. Ini termasuk Petruk Dadi Ratu, Layang Kalimasada, Dewa Ruci, Pandu Pragola, Semar Mbarang Jantur, Mustakaweni, Begawan Ciptaning, Obong Bale Sigala-gala, Wahyu Widayat, Kresna Gugah, dll. Karya sastra yang diubahnya antara lain "Buku Bonang" (Suluk Sunan Bonan), Suluk Wujil, Suluk Khalifa, Sulu Kaderesan, Suluk Regol, Sulu Bentur, Suluk Wasiyat, Suluk Pipiringan, Gita Suluk Latri, Gita Suluk Linglung, Gita Suluk ing Aewuh, Suluk Jebeng, Suluk Wregol dll. Suluk-suluk ini berisi lika-liku kehidupan Sunan Bonang dalam perjalanan tarekat. 


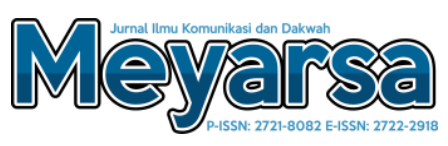

atau rakyat menjadi sarana dakwah, seperti wayang kulit dan lagu. ${ }^{4}$

Sederhananya, dapat dipahami bahwa dengan munculnya budaya Jawa dan integrasi doktrin agama yang mengisi ruang sosial keagamaan maka terjadi proses integrasi budaya dalam masyarakat. Pertengahan kehidupan komunitas dibentuk oleh koeksistensi banyak budaya sebelumnya dan kultur terkini yang ada. Salah satu sampelnya adalah adanya budaya slametan. Budaya Muslim sebenarnya adalah budaya kuno agama Jawa yang disesuaikan dengan nilai-nilai Islam.

Strategi dakwah Wali Songo memberi tahu kita bahwa Islam bisa muncul dalam budaya yang mengembang, asalkan tidak berlawanan dengan hakikat Islam, tidak masalah. Oleh karena itu, Islam tidak dianggap sebagai doktrin yang bertentangan secara diametral dengan kultur lokal, tetapi Islam memberkati dunia semesta dengan nilai universal.

Namun sekarang, Dakwah sedang mengalami perkembangan teknologi informasi yang semakin modern. Dengan adanya hal tersebut membuat banyak orang yang mengabaikan akidah Islam. Wisril dan Abdul Mugni Shaleh mengajukan contoh sederhana dari kegiatan yang ada, seperti: duduk di depan TV dalam waktu lama, terlalu lama menggunakan internet, sehingga waktu salat berakhir, bahkan ada yang meninggalkan salat. Ini merupakan fenomena kegiatan keagamaan masyarakat dan membutuhkan konsep baru untuk mengimplementasikan konsep dakwah. Bagi umat Islam yang telah ditinggalkan dan melakukan kejahatan, dakwah sendiri

4 Ridin Sofwan, dkk, Islamisasi di Jawa, (Yogyakarta: Pustaka Pelajar, 2004), h. 262. merupakan kewajiban. Oleh karena itu, sekarang perlu dilakukan dakwah secara modern dan profesional dengan tetap menjaga hakikat ajaran Islam

Untuk saat ini masyarakat tentunya mempunyai akses media sosial dan jaringan internet, dan dengan pertumbuhan internet dan perkembangan IT telah mengakibatkan perkembangan metode dalam berdakwah. Para da'i pun sudah mulai menggunakan kemajuan teknologi informasi untuk mentransfer pengetahuan mereka. Memanfaatkan teknologi informasi, kegiatan dakwah dapat dilakukan dengan lebih gencar dan melalui jaringan yang lebih luas. Menurut pernyataan Kementerian Komunikasi dan Informasi, 95\% dari 63 juta orang Indonesia memakai internet untuk mengakses situs jejaring sosial. Oleh karena itu, menggunakan internet sebagai media media dakwah dapat menjadi pilihan yang efektif untuk berdakwah Islam. Contoh media sosial yang sering dipakai saat ini diantaranya yaitu: Facebook, Instagram, YouTube, Twitter, dan WhatsApp (WA).

Dilihat dari kecepatan penyebaran informasi ke segala arah, penggunaan media sosial untuk berdakwah juga sangat efektif. Manfaat menggunakan media sosial untuk dakwah juga banyak sehingga memudahkan mad'u mendapatkan informasi keagamaan. Semua penjuru dapat menikmati dakwah melalui media sosial, karena penting untuk diingat bahwa dakwah bukan saja dilaksanakan diatas podium, melainkan dapat dilaksanakan dengan beragam metode.

Seperti yang diungkapkan oleh salah satu kiai di tuban yaitu kiai Mujahiddin Almubarok."saya berdakwahnya lewat online juga,karena saya memandang ladang dakwah yang paling hebat dijaman 


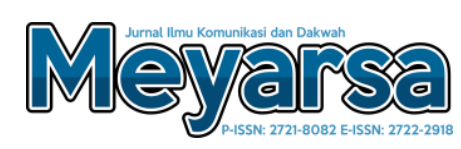

akhir itu online, kenapa saya tidak memanfaatkan seperti itu? Lah ngaji kitab di online dan lain-lain, membuat grup WA dan lain-lain, kenapa tidak saya manfaatkan. Akhirnya jama'ah saya bertambah."5

Dari uraian barusan, bisa dirangkum bahwasannya berdakwah dari tahun ke tahun semakin berkembang, yang mana pada era sebelumnya para wali khususnya sunan Bonang berdakwah dengan menggunakan budaya jawa seperti gending jawa dsb. Dan pada era sekarang para da’i lebih memanfaatkan teknologi seperti media sosial.

Dakwah Multikultural dan Problematika Masyarakat Modern

Ditilik dari segi etimologi atau bahasa, dakwah muncul dari bahasa Arab, yang bermakna panggilan, ajakan, atau seruan. Kata dakwah berwujud "isim masdar" yang berpangkal dari fiil (kata kerja) “da'a” (دعام) "yad'u” (يدعو) "da'watan" (دعوة) yang berarti memanggil, mengajak, atau menyeru. ${ }^{6}$ Sedangkan pengertian dakwah secara terminologi yeng telah dikemukakan oleh para ahli adalah sebagai berikut:

Profesor Toha Yahya Umar, dalam bukunya "Ilmu Dakwah" yang dimaksud dengan "Dakwah" adalah mengajak orang ke jalur yang intensif dengan cara yang bijak selaras dengan tuntunan Tuhan, dengan maksud meminta kepada mereka kesejahteraan dan ketentraman di alam semesta dan seterusnya. ${ }^{7}$

Dalam bukunya "Psikologi Dakwah Suatu Pengantar Studi”, Profesor HM Ariffin M.

${ }^{5}$ Hasil wawancara dengan Kiai Mujahidin pada tanggal 30 April 2021.

6 Saputra, Pengantar Ilmu Dakwah, (Jakarta: PT Raja Grafindo Persada, 2011), h. 1.

7 Samsul Munir Amin, Ilmu Dakwah, (Jakarta: Hamzah, 2009), h. 3.
Ed mendefinisikan Dakwah bagaikan suatu aktifitas ajakan, dengan ucapan, catatan, akhlak, dan bentuk lainnya. akhlak ini dilaksanakan secara sadar, dan merupakan tingkah laku yang mempengaruhi orang lain dalam rencana tersebut. Dilakukan dengan individu maupun kelompok, agar memiliki pemahaman, pengetahuan, sikap, penghargaan dan pengamalan agama, inilah pesan yang diberitahukan kepadanya tiada adanya faktor tekanan atau desakan. ${ }^{8}$

Asmuni Syukir mendefinisikan kata dakwah dari dua aspek dalam bukunya " Dasar-dasar Strategi Dakwah Islam", makna dakwah adalah pembinaan dan pengembangan. Konsep pembinaan dakwah adalah menegakkan hukum syariah agar membuat manusia yang sejahtera di alam semesta dan di akhirat, sedangkan pengertian dakwah dalam konsep perkembangan adalah mengajak mereka yang belum percaya kepada Allah dan mematuhi hukum Syariah Islam untuk (memeluk Islam) agar dapat hidup sejahtera di alam semesta ini dan di akhirat. ${ }^{9}$

Dakwah multikultural dapat dikatakan secara sederhana sebagai pengakuan atas keberadaan keragaman budaya yang dihargai Muslim. Multikulturalisme telah menjadi paham tentang multikulturalisme, yang intinya mengakui martabat masyarakat yang tumbuh dalam khalayaknya dengan budaya sendiri-sendiri yang eksklusif. Oleh karena itu, masingmasing orang sadar bahwa mereka berharga, dan pantas mendapatkannya, harus bertanggung jawab atas kehidupan bersama dalam komunitas mereka sendiri. Kebutuhan akan pengakuan (needs for

8 Ibid., h. 4.

9 Asmuni Syukir, Dasar-Dasar Strategi Dakwah Islam, (Surabaya: Al-Ikhlas, 1983), h. 20. 


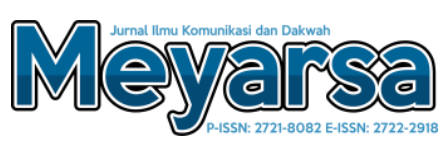

recognition) merupakan sumber ketidak seimbangan di semua bidang kehidupan. ${ }^{10}$

Bikhu Parekh mengatakan bahwa orang multikultural merupakan orang yang dengan eksplesit berkenan memahami variasi dari minoritas dan memberikan kesempatan kepada minoritas untuk bertahan hidup, berkedudukan, dan memberi mereka tempat selebar mungkin. kemudian kaum mayoritas tanpa harus khawatir atau terancam terhadap keberadaan kaum minoritas yang memberikan "jalan lain" bagi kaum mayoritas masyarakat yang sudah usang menikmati partisipasi dan tempat politik yang aman serta beragam profesi yang mereka peroleh sepanjang ini. Singkatnya, orang multikultural adalah seseorang yang memahami minoritas dan statusnya sebagai mayoritas yang beritikad baik terhadap minoritas. ${ }^{11}$

Dari sinilah sebenarnya dakwah multikultural berpangkal dari paham klasik dakwah kultur, yakni pemahaman tentang legalitas budaya lokal dan kearifan dalam doktrin Islam tidak berselisih dengan anjuran tauhid. Hanya saja misi multikultural melangkah seterusnya dalam kekuatan atau kelapangan budaya mereka. Jika pola kultural hanya menitik beratkan pada bagaimana menyampaikan persoalan Islam melalui kesepakatan dengan kultur tertentu, maka Dakwah multikultural akan mempertimbangkan bagaimana menyampaikan pesan-pesan Islam ini dalam masyarakat majemuk tanpa menyertakan unsur "monism moral". Itu dapat menghancurkan berbagai budaya dan kepercayaannya sendiri.

10 Tilaar, Kaleidoskop Pendidikan Nasional, (Jakarta: Kompas, 2012), h. 919-920.

11 Azyumardi Azra, dkk, Fikih Kebinekaan, (Bandung: Mizan, 2015), h. 182-184.
Pendekatan multikulturalis mencoba melihatkan banyak orang sebagai keunikan mereka sendiri, dan tidak boleh memaksa mereka untuk bersatu, tetapi harus beroperasi secara harmonis dalam keberagaman. Intinya, pendekatan dakwah terhadap multikulturalisme berupaya menggapai 2 hal, yaitu titik temu keberagaman dan keterbukaan terhadap disimilaritas. Gagasan multikulturalisme dakwah merupakan spekulasi dakwah yang melibatkan dialog untuk menemukan persetujuan atau konsensus tentang hal-hal yang dapat disetujui, dan diberagam tempat untuk hal-hal yang tidak disetujui. sehingga dapat menyampaikan pesan Islam dalam konteks masyarakat majemuk. ${ }^{12}$

Dakwah di era kontemporer menghadapi beragam tantangan dan permasalahan yang bertambah terik. Hal tersebut tidak terlerai dari kemajuan dan motivasi masyarakat yang bertambah maju dan sistematis. Dalam masyarakat agraris yang aktivitas manusianya penuh dengan kesahajaan, pastinya terdapat permasalahan hidup yang berlainan dengan masyarakat modern masa kini, masyarakat saat ini cenderung ke materialisme dan individualisme. Demikian pula tantangan dan masalah dakwah juga akan menghadapi berbagai masalah yang sesuai dengan kebutuhan zaman sekarang. ${ }^{13}$

Karena kegiatan dakwah tidak dapat dipisahkan dari masyarakat, maka kemajuannya harus berbanding lurus dengan kemajuan masyarakat. Dengan

12 A. Ilyas Ismail dan Prio Hotman, Filsafat Dakwah: Rekayasa Membangun Agama dan Peradaban Islam, (Jakarta: Kencana, 2011), h. 262264.

13 Bobby Rachman Santoso, "Revitalisasi Metode Dakwah Anakronistis Dai Generasi Milenial", Jurnal Tasamuh UIN Mataram, Vol. 17, No. 1 (2019), h. 133-134. 
kata lain, kegiatan dakwah harus bisa mengikuti perkembangan dan perubahan sosial. Sejauh ini, kegiatan misionaris (Dakwah) jauh dari perkembangan dan perubahan sosial sehingga dakwah tampaknya berjalan di tempat. Masyarakat belum menggunakan dakwah sebagai pedoman atau panduan untuk merespon perubahan yang terjadi.

Berbagai bentuk aktivitas dalam masyarakat modern menghadapi tantangan, seperti tindakan memperoleh hiburan, pariwisata dan seni dalam arti luas, yang semakin memberikan keluangan bagi kerentanan adab dan akhlak. Ancaman adab dan akhlak tampil lebih transparan dalam bentuk yang tidak etis karena didukung oleh perkembangan perangkat teknologi informasi terkini (seperti siaran televisi, preservasi VCD, internet, dll). Perilaku asusila selalu meningkat secara nilai dan keunggulan, seperti mencoloknya perjudian, minuman keras, narkoba, dan perilaku kriminal, serta menjamurnya kawasan-kawasan hiburan pada siang atau malam hari yang kesemuanya merupakan transaksi dan penghinaan budaya etis dan rasa malu.

Tak heran, akhirnya di negeri dengan budaya, adat istiadat dan kepercayaan agama ini, perilaku tidak etis terkait dengan apa yang disebut industri seks juga berkembang, apalagi setelah dibukanya pariwisata internasional diberbagai daerah, perilaku ini semakin meluas, bertambah besar generasi muda dan remaja kehilangan karakter mereka dan semakin kurangnya keteguhan hati dan pengetahuan.

Hal yang selanjutnya menjadi bertambah buruk karena pertumbuhannya yang mengkhawatirkan, disebabkan hampir tidak ada batasan diantara daerah perkotaan dan pedesaan, dan semua batas tercemar oleh eforia kebebasan tanpa batas. Jangan sampai kemajuan informasi dan teknologi di berbagai bidang meledak sembarangan. Kita mesti bekerja keras untuk menangkal dan menghalangi dengan memperkukuh benteng akidah yang memadukan iptek. Banyak korban gugur, yang membikin kejayaan Islam bertambah gawat, dan kala nanti generasi muda bertambah gelap. Jika kita lalai dan kecanduan dengan berbagai kelimpahan dalam hidup dengan beragam falisitasnya, maka lama-kelamaan kita akan melalaikan ajaran Allah yang esensial bagi akhlak kita masing-masing.

Selain itu, kekurangaan dan tertinggalannya umat Islam dalam memperoleh pengetahuan dari waktu ke waktu yang pada akhirnya akan membikin aktivitas dakwah kita semakin membosankan dan tidak bertenaga. Bertumpu dari aspek-aspek tersebut, agar masalah dakwah bukan lagi terbelit dan ditunda, butuh secepatnya dicari cara untuk situasi dari masalah yang ada saat ini. Dalam buku M. Amien Rais yang berjudul "Politik Muhamadiyah" menjelaskan ada 5 aktivitas rumah yang harus dikerjakan, agar di era informasi dakwah Islam dapat tetap efektf, produktif, dan relevan: ${ }^{14}$

Harus ada pengkaderan yang serius untuk melatih dai dan membuat pengelompokan kerja mereka rapi. dakwah saja belum cukup untuk membantu tahapan dakwah, dan dibutuhkan beragam keterampilan ilmu teknologi informasi terkini.

Setiap organisasi Islam yang tertarik dengan misi dakwah butuh mendirikan laboratorium dakwah. Dari akibat "Labda"

14 Nurhidayat Muh. Said, "Dakwah dan Problematika Umat Islam", Jurnal Dakwah Tabligh, Vol. 14, No. 1, Juni 2013. 
ini nantinya bisa ditemukan problem yang sebenarnya di lapangan, sehingga jelas apa yang kedepannya dikerjakan.

Tahapan dakwah hendaknya tidak spesifik pada dakwah ucapan, tetapi dilebar dengan dakwah bil-hal, bil-kitaabah (melalui tulisan), bil-hikmah (dalam arti politik) biliqtishadiyah (ekonomi), dan masih banyak lagi.

Sekarang kita harus memperhatikan media massa cetak, khususnya media elektronik. Umat Islam perlu memiliki media elektronik yang dapat digunakan sebagai media dakwah atau sarana dakwah. Jika suasana di Indonesia kedepannya dipenuhi dengan informasi dari agama lain, namun tidak ada informasi dari Islam, maka situasi ini tentunya tidak kondusif bagi pengembangan ajaran Islam di nusantara.

Mengambil pemuda nusantara merupakan keharusan pada jangka panjang dakwah Islam. Anak-anak dan pemuda kita merupakan kekayaan yang berharga. Kita harus menyelamatkan mereka dari erosi Akidah akibat serbuan nilai-nilai nonIslam ke dalam hati beragam khalayak Islam di nusantara. Jika di era globalisasi dan pengetahuan sekarang ini, anak-anak dan generasi muda kita mempunyai benteng pertahanan yang kuat (al-hususn al-hamidiyyah), Insya Allah, kala nanti dakwah kita masih berjalan lancar.

Mengamati deskripsi tersebut, dapat diramalkan bahwa tugas dan ancaman dakwah tidak akan pernah berkurang, tetapi akan menjadi lebih berat, lebih intens, bahkan lebih rumit dan lumer. Inilah masalah dakwah kita era ini. Oleh karena itu, semua urusan harus dikelola kembali oleh manajemen dakwah yang ahli dan didedikasikan oleh staf yang berkontribusi tinggi yang rela berkhitmat dan beramal saleh dengan itikad baik.
Menilik kemampuan atau kapasitas umat Islam masih sangat spesifik atau terbatas, walaupun kita harus beradaptasi dengan segala problem dan ancaman yang timbul, sebaiknya mencoba memilih dan menjemput orang-orang yang cocok untuk menghadapi permasalahan tersebut. Sehingga pendanaan, energi dan ide Penggunaannya bisa lebih terarah, efektif dan produktif.

Di era modern ini, persoalan misi menjadi semakin pelik. Ini tidak lepas dari kemajuan masyarakat. Dalam masyarakat agraris, kehidupan manusia penuh dengan kesederhanaan, tentunya persoalan kehidupan berbeda dengan masyarakat modern yang seringkali bersifat materialistis dan individualistis. Begitu pula dengan tantangan masalah dakwah akan menghadapi berbagai masalah yang sesuai dengan kebutuhan zaman sekarang. Permasalahan dakwah dalam masyarakat modern antara lain: pertama, pengertian umum dakwah pada masyarakat awam lebih diartikan sebagai komunikasi verbal (tabligh), sehingga kegiatan dakwah lebih difokuskan pada kegiatan caramah. Kedua, masalah epistemologis. zaman sekarang tidak hanya konvensional, temporal dan instan, tetapi juga membutuhkan paradigma ilmiah. Tentunya dengan adanya ilmu dakwah, hal-hal yang berkaitan dengan strategi dan langkahlangkah teknis dapat dirujuk melalui teori dakwah. ketiga, masalah yang berhubungan dengan sumber daya manusia.

\section{Implementasi Dakwah Multikultural Era Modern Kiai-kiai Lokal Di Tuban}

Landasan spekulasi dakwah multikultural sebenarnya berasal dari paham klasik dakwah budaya, yaitu validitas doktrin 
Islam tentang keberadaan budaya dan pemahaman keindahan lokal tidak berlawanan dengan prinsip kepercayaan. Intinya, strategi dakwah terhadap multikulturalisme bergerak menjangka 2 hal, yaitu titik temu keberagaman dan solidaritas terhadap keberagaman. Ismail meyakini bahwa paradigma baru misi yang berbasis globalisasi dan perkembangan politik aktual, serta misi yang berbasis dakwah multikulturalisme mempunyai identitas tersendiri. Kawasan masyarakat multikultural penuh dengan konflik.

Salah satu masalah terbesar dalam kehidupan beragama adalah fakta keberagaman, yaitu bagaimana teologi agama mengartikan dirinya dalam agama lain. Seiring berkembangnya pemahaman tentang pluralisme agama, begitu pula teologi agama. Pemahaman ini menekankan pentingnya melakukan teologi dalam konteks keagamaan. Secara pribadi, relasi antar pemuka agama Indonesia mungkin tidak menjadi masalah. Namun pada tataran teologi yang menjadi basis agama, bisa timbul kebingungan, terutama terkait bagaimana kita hendaknya mendeskrisikan diri kita sendiri di antara agama-agama yang lainnya juga ada.

Islam adalah agama yang berinteraksi dengan budaya dan tradisi lokal yang sudah ada sebelumnya. Kombinasi ini disebut sinkretisme. Sinkretisme merupakan hal yang tidak dapat dijauhi di persimpangan satu kultur dan kultur lain, dan itu dapat mengarah pada kultur baru yang dibagikan dan diikuti seraya. Selama ini sinkretisme masih ada dalam komunitas muslim di Tuban. Ritual ibadah ziarah kubur adalah salah satu hasil dari sinkretisme di Indonesia.

Kegiatan ziarah seluruh masyarakat Jawa dan pesisir Tuban berulangkali diikuti dengan adat istiadat yang menjiplak tradisi sebelum Islam, dan sebagian masyarakat menganggap kegiatan tersebut sebagai kegiatan syirik. Terkadang peziarah tidak tahu jamaah mana yang sebenarnya adalah tuntunan dalam Islam, dan mana yang meggambarkan budaya atau kultur yang diwarisi oleh budaya klasik atau tradisi nenek moyang. Ziarah masyarakat Indonesia telah menjadi tradisi dalam komunitas muslim Indonesia di semua wilayah. Ziarah yang dilakukan sama Islam nyaris tanpa mengganti budaya ziarah warga atau rakyat sebelumnya. ${ }^{15}$

Meski era ini telah memasuki era digital, namun masyarakat di Tuban cenderung masih memelihara kultur yang sudah turun-temurun dari nenek moyang, seperti tahlilan, witonan, syukuran, upacara kematian dsb. Nah dengan adanya budaya yang masih dilestarikan oleh masyarakat Tuban, para kiai lokal memanfaatkan hal tersebut untuk dakwahnya. ${ }^{16}$

Tahlil menggambarkan kejadian umum yang merekat dalam kultur Muslim Jawa. Hal tersebut tidak luput asal mula lakon dakwah Walisanga yang mempertahankan formula tradisi Jawa dengan mengganti substansinya dengan ajaran-ajaran Islam. ${ }^{17}$ Terkadang tahlilan pada masyarakat Tuban dilaksanakan pada beberapa acara, contohnya syukuran pada hari kemerdekaan Indonesia, syukuran acara pernikahan, doa bersama menolak balak yang dilakukan di persimpangan jalan, 7 bulanan atau disebut juga tingkepan,

15 Siti Mukzizatin, Meneropong Perilaku Keberagamaan Masyarakat Pesisir Tuban Rekonstruksi Strategi dan Metode Dakwah Wali Songo, Jurnal Bimas Islam, Vol. 11. No. II.

16 Hasil wawancara dengan Kiai Jupriyanto pada tanggal 6 Mei 2021.

17 Lihat: Abdurrahman Mas'ud, Intelektual Pesantren, (Yogyakarta: LKIS, 2004), h. 47-48. 
syukuran lahirnya bayi, selapan, 6 bulanan bayi, dan ada pula upacara kematian yang meliputi tiga harinya, tujuh harinya, empat puluh harinya, seratus harinya, dan 1000 harinya. Bahkan adapula kumpulan ibu-ibu yang meliputi ibu fatayat, ibu tahlil, ibu arisan. kumpulan bapak-bapak meliputi kumpulan RT tiap minggu. Kumpulan pemuda meliputi IPNU-IPPNU, pemuda ANSOR, dan juga Pagar Nusa yaitu pencak silat di dalam naungan Nahdlotul Ulama'.18 Penjelasan tersebut merupakan beberapa kegiatan Nahdlotul Ulama', di tuban ini lebih dominan aliran NU dan Muhamadiyyah. Untuk kiai NU sendiri dalam dakwah multikultural ini memanfaatkan kegiatan-kegitan di atas, bahkan dulu bisa disebut juga P2A (Pembina, Pelaksana Agama).

Kegiatan dan organisasi aliran Muhamadiyah sendiri meliputi: 1). 'Aisyiah yang merupakan sebuah gerakan perempuan Muhammadiyah dibermacammacam bidang yaitu:pendidikan, kesehatan, kesejahteraan sosial, ekonomi dan pemberdayaan masyarakat, 2). Pemuda Muhammadiyah (PM), 3). Nasyiyatul 'Aisyiyah (Nasyiah), 4). Ikatan Pelajar Muhammadiyah (IPM) yang merupakan organisasi Muhammadiyah dikalangan pelajar, 5). Ikatan Mahasiswa Muhammadiyah (IPM) yang merupakan tindakan mahasiswa Islam yang berakidah Islam dan berasal dari AL-qur'an dan Assunnah, 6). Tapak Suci (TS) merupakan sebuah tarekat, perguruan, dan organisasi pencak silat dan merupakan anggota IPSI, 7). Hizbul Wathan (HW) atau pramuka Muhammadiyah.

Ada pula kegiatan yang menyeluruh di Tuban adalah wisata rohani yang dilaksanakan setiap hari minggu pagi di

18 Hasil wawancara dengan Kiai Jupriyanto pada tanggal 6 Mei 2021. masjid-masjid kecamatan yang ada di Tuban (kegiatan NU). Dan di setiap hari kamis (milik kegiatan semua Islam di Tuban:NU, Muhamadiyah). ${ }^{19}$ Era modern ini kegiatan dakwah dilakukan dengan memanfaatkan IT (Information technology), seperti contoh pengajian rutin setiap hari jum'at dengan streaming di salah satu kecamatan yang ada di Tuban. ${ }^{20}$

Pendekatan dakwah multikultural di era modern ini kiai Tuban yang pertama melalui karakter mad'u, yang mana da'I mempelajari karakter mad'unya seperti apa, kemudian memahami karakternya. kemudian yang yang kedua ialah mengambil hatinya, nah jika memang sudah memahami karakter mad'u seperti apa, kemudian mencari cara agar mad'u tersentuh hatinya, kemudian mad'u tersebut berkenan mematuhi apa yang diperintahkan da'I tersebut. ${ }^{21}$

Seperti yang dicotohkan kiai Mujahiddin ialah ada salah satu mad'uya yang suka dengan minum-minuman keras, bahkan bisa disebut juga hobinya minumminuman keras, akan tetapi dia memiliki sisi positif dalam dirinya yaitu dermawan. Nah di sini kiai Mujahidin tidak membahas tentang kemaksiatannya, melainkan membahas tentang kelebihannya. Bahkan kiai Mujahidin pun tidak menghakiminya, tidak menyalahkannya. Kemudian setiap harinya kiai Mujahiddin memujinya dengan kelebihan yang dia miliki, sehingga hati mad'u tersebut luluh kemudian tertarik mengikuti kiai Mujahidin. ${ }^{22}$

Pintu-pintu untuk mendekatkan diri kepada Allah bukan hanya lewat kebaikan saja, terkadan Allah memanggil hamba-

19 Ibid.

20 Ibid.

21 Hasil wawancara dengan Kiai Mujahidin pada tanggal 6 Mei 2021.

22 Ibid. 


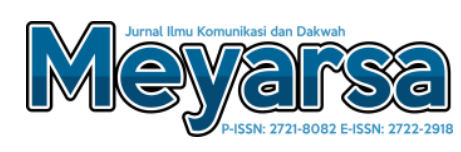

Nya lewat kemaksiatan. Contoh: Allah memberikan ujian terhadap hamba-Nya lewat musibah sakit melalui kemaksiatan yang diperbuat. Seperti minum-minuman keras, dari sini ketika dia peminum akibatnya rumah tangganya hancur, anaknya nakal, bahkan dia sendiri penyakitan. Dengan dia diuji seperti ini mengakibatkan dia semakin dekat dengan Allah dan bertaubat. Karena di dunia ini apabila perbuatan kita baik maka balasannya juga akan baik, dan sebaliknya apabila perbuatan kita jelek maka balasannya akan jelek juga. Semua prilaku yang kita kerjakan di alam semesta ini bakal ada jawabannya langsung di dunia maupun di akhirat. Dakwah multikultural mengajarkan kita bahwasanya "mengajak tanpa menginjak, dan menasehati tanpa menyakiti”.

\section{Peran Dakwah Multikultural Era Modern Kiai-kiai Lokal Terhadap Masyarakat Tuban}

Umat manusia diciptakan di bumi ini banyak ragamnya, tentu keberagaman di dunia ini adalah sebagai kerisaian bagi kita semua. Karena keberagaman itu sebagai keniscaan, maka kita harus tanamkan di dalam diri, di dalam hati kita bahwa ketika kita menghadapi sebuah keberagaman ini maka kita harus bersikap bijak, toleran, terbuka terhadap keberagaman itu, sehingga kita semua akan senantiasa menyikapinya dan hidup berdampingan secara damai. Ladasan dari keberagaman sudah dijelaskan oleh Allah dalam QS. AlHujurat ayat 13: Yang artinya: "Wahai manusia! Sungguh, Kami telah menciptakan kamu dari seorang laki-laki dan seorang perempuan, kemudian Kami jadikan kamu berbangsa-bangsa dan bersuku-suku agar kamu saling mengenal. Sesungguhnya yang paling mulia di antara kamu di sisi Allah ialah orang yang paling bertakwa. Sungguh, Allah Maha Mengetahui, Mahateliti."

Dari ayat tersebut mendefinisikan bahwasannya Allah mewujudkan manusia itu dalam bentuk yang beragam, dan itu tugas manusia adalah lebih mengenal, lebih memperdalam, lebih memahami apa yang ada disamping kanan-kiri kita. Sehingga keberadaan ayat ini mempertegas dan menjadi dasar kepada kita semuanya bahwa kita sebagai manusia itu tidak ada yang lebih mulia kecuali yang bertaqwa, tidak ada yang lebih baik selain orang yang lebih bermanfaat. Apapun kondisinya kita ini memberikan manfaat kedapa orang lain, maka untuk memahami itu semua tentu kita harus lebih belajar lagi kepada para pendahulu kita yang pertama ialah suri tauladan yaitu Rasulullah SAW.

Dakwah multikultural era modern sangatlah berperan, karena dunia sekarang ini semakin maju, dengan majunya teknologi-teknologi orang semakin lalai akan perannya menjadi manusia, semakin malas-malasan, bahkan cenderung penikmat teknologi tersebut, misal: kebanyakan orang lebih suka menonton youtube, penikmat sosial media, penikmat game. Padahal orang yang membuat game, membuat aplikasi-aplikasi tersebut kebanyakan orang nasrani, sedangkan orang Islam hanya penikmat saja. Oleh karena itu kita harus memanfaatkan aplikasi-aplikasi tersebut digunakan untuk hal kebaikan. Contohnya berdakwah lewat streaming. Dan kalau bisa kita jangan diperbudak oleh teknologi melainkan teknologi kita perbudak. ${ }^{23}$

Dalam dakwah pastinya Kiai sangatlah berperan penting, apalagi di era yang sekarang ini, pemuda atau generasi

${ }^{23}$ Ibid. 
milenial ini moralnya semakin memburuk. Karena adanya budaya asing yang telah masuk di negara kita, khususnya di Tuban. Sehingga budaya asli yang ada di Tuban semakin terkikis oleh keadaan, banyak pemuda yang lebih menyukai budaya asing dan melupakan budaya kita sendiri. Di sinilah Kiai pun juga harus mengikuti perkembangan zaman yang semakin maju, Karena agar dakwah tetap berjalan dengan efektif.

Pemuda Tuban di era modern ini karakternya tidak seperti pemuda pada zaman dulu, yang mana pemuda zaman sekarang tidak mempan atau tidak efektif jikalau didakwahi dengan cara ceramah, pengajian dan sebagainya. Di sinilah seorang Kiai Tuban harus mengetahui kebutuhan apa saja yang diperlukan pemuda pada saat ini. Jika pemuda sekarang bahasanya gaul, maka Kiaipun juga bahasanya harus gaul. Jika pemuda sehari-harinya dihabiskan untuk bermain gadget, maka Kiai juga harus bisa bermain gadget, misalnya: pemuda sekarang atau masyarakat sekarang bermain Tik-Tok, joget-joget di Tik-Tok, maka Kiai pun juga harus memiliki akun Tik-Tok yang diisi dengan ceramah, kata-kata mutiara, video dakwah, dan sebagainya. Nah dari sini dakwah bisa dilakuka dengan efektif karena mengikuti perkembangan zaman. ${ }^{24}$

Ketika Kiai hanya dengan media kuno, memilih bungkam tidak mengikuti zaman yang telah berkembang, maka dakwahnya tidak akan efektif, karena pemuda atau masyarakat saat ini kesehariannya dipenuhi dengan hanphone (media sosial) maka Kiai ang seperti ini akan ketinggalan zaman. Peran Kiai pada era modern ini yaitu mendorong pemuda saat ini agar aktif

${ }^{24}$ Ibid. dalam media sosial, akan tetapi untuk halhal kebaikan.

Era digital ini surga dan neraka berada diketikan jari kita, karena jika kita mengunggah kemaksiatan, maka dosa akan mengalir terus, apalagi yang melihat unggahan kita semakin banyak maka semakin banyak pula dosa kita. Akan tetapi jika kita menunggah hal-hal positif, maka pahala pun akan mengalir deras kepada kita. Misalnya kita mengunggah tentang dosa besar jika berani kepada orang tua, kemudian yang melihat unggahan kita langsung terenyuh dan meminta maaf kepada orang tuanya, maka kita akan dialiri dengan pahala yang banyak. ${ }^{25}$

Era modern ini sebenarnya membuka peluang bagi dai-dai yang tergolong multikultural untuk mengintegrasikan dakwah berbudaya melalui media modern. Dakwah Islam di Tuban yang diaplikasikan dai dengan kemasan multimedia akan memudahkan diterimanya agama Islam bagi masyarakat. Para remaja yang mayoritas memanfaatkan media modern semakin memiliki minat terhadap dai yang berbudaya.

\section{Kesimpulan}

Dakwah dari tahun ke tahun pasti ada perubahannya, di Tuban pada dahulu kala dakwah yang digunakan para Wali terutama Sunan Bonang dakwahnya menggunakan berbagai budaya Jawa seperti gending jawa, dan beliau juga membuat beberapa karya sastra seperti Suluk Wujil, Suluk Khalifah, Suluk Regok, Suluk Bentur, Suluk Wasiyat, Suluk Ing Aewuh, Suluk Pipiringan, Suluk Jebeng, dll. Sedangkan dakwah pada era modern 


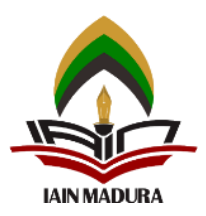

ini lebih memanfaatkan IT (Information Teknologi) seperti sosial media.

Dakwah multikultural mempertimbangkan bagaimana menyampaikan pesan-pesan Islam ini dalam masyarakat majemuk tanpa melibatkan unsur "monism moral". Itu dapat menghancurkan berbagai budaya dan kepercayaannya sendiri. Dakwah di era kontemporer menghadapi berbagai tantangan dan permasalahan yang semakin kompleks. Hal tersebut tidak terlepas dari perkembangan dan motivasi masyarakat yang semakin maju dan beradab Karena kegiatan dakwah tidak dapat dipisahkan dari masyarakat, maka perkembangannya harus berbanding lurus dengan perkembangan masyarakat.

Penerapan dalam dakwah multikultural era modern ini kiai Tuban melalui pendekatan karakter mad'u, yang mana kiai mempelajari karakter mad'unya seperti apa, kemudian memahami karakternya. kemudian yang yang kedua melalui pendekatan hati, atau mengambil hatinya si mad'u, nah jika memang sudah memahami karakter mad'u seperti apa, kemudian mencari cara agar mad'u tersentuh hatinya, sehingga mad'u tersebut mau mengikuti apa yang diperintahkan kiai tersebut. Karena keberagaman itu sebagai keniscaan, maka dari itu peran dakwah multikultural era modern kiai-kiai lokal terhadap masyarakat sangat penting karena agar terciptanya hidup secara damai, makmur, dan sejahtera.

\section{Daftar Pustaka}

Amin, Samsul Munir. 2009. Ilmu Dakwah. Jakarta: Amzah.

Azra, Azyumardi dkk. 2015. Fikih Kebinekaan. Bandung: Mizan.
Ismail, A. Ilyas dan Prio Hotman. 2011. Filsafat Dakwah: Rekayasa Membangun Agama dan Peradaban Islam. Jakarta: Kencana.

Mas'ud, Abdurrahman. 2004. Intelektual Pesantren. Yogyakarta: LKIS.

Mukzizatin, Siti. 2018. Meneropong Perilaku Keberagamaan Masyarakat Pesisir Tuban Rekonstruksi Strategi dan Metode Dakwah Wali Songo. Jurnal Bimas Islam Vol.11. No.II: 250.

Said, Nurhidayat Muh. 2013. Dakwah Dan Problematika Umat Islam. Jurnal Dakwah Tabligh, Vol. 14, No. 1.

Santoso, Bobby Rachman. 2019. Revitalisasi Metode Dakwah Anakronistis Dai Generasi Milenial. Tasâmuh 17.1: 133154.

Saputra. 2011. Pengantar Ilmu Dakwah. Jakarta: PT Raja Grafindo Persada.

Sofwan, Ridin dkk. 2004. Islamisasi di Jawa. Yogyakarta: Pustaka Pelajar.

Syukir, Asmuni. 1983. Dasar-Dasar Strategi Dakwah Islam. Surabaya: AlIkhlas.

Tilaar. 2012. Kaleidoskop Pendidikan Nasional. Jakarta: Kompas.

Wawancara dengan Kiai Jupriyanto pada tanggal 6 Mei 2021.

Wawancara dengan Kiai Mujahidin pada tanggal 6 Mei 2021. 